\title{
Institutional Assets and Adaptability: NATO After the Cold War
}

\author{
Celeste A. Wallander
}

What happens to alliances when their precipitating threats disappear? Understood in realist terms, alliances should not outlive the threats they were created to address. As coalitions of states aggregating their capabilities to cope with common enemies, alliances should have no purpose beyond deterrence or defense, and no resources beyond the power and purpose of their members. ${ }^{1}$ When threats disappear, allies lose their reason for cooperating, and the coalition will break apart. Consistent with the theoretical underpinnings of realist theory, early in the post-Cold War period many scholars predicted NATO's demise. ${ }^{2}$

Yet a decade after the disappearance of the Soviet threat, NATO still exists. To explain the persistence of NATO, we must first accept that alliances are not always merely aggregations of national power and purpose: they can be security institutions as well. As institutions, alliances themselves make a difference in the capacity of states to coordinate their policies and mount credible deterrence or defense. ${ }^{3}$ Institutions persist because they are costly to create and less costly to maintain, so they may remain useful despite changed circumstances. ${ }^{4}$ However, this institutionalist argument is incomplete. The concept of "sunk costs" alone does not tell us when institutions will persist-clearly, many institutions (such as the Warsaw Pact) do not.

In this article I develop an explanation for institutional adaptation to explain variation in institutional persistence. An institution will not persist if it no longer serves the interests of its members, and so alliances predicated only on threats are unlikely to survive when the threats disappear. But unlike mere alignments of states, security

I thank Robert Art, Bat Batjargal, Jeffrey Checkel, Richard Falkenrath, Peter Gourevitch, Robert Keohane, David Lake, Lisa Martin, and two anonymou s reviewers for their comments on earlier versions of this article. I am especially indebted to Keohane for our work together on security institutions over several years, without which I could not have developed the ideas and research that led to this article, and to Jim Goldgeier for generously sharing his knowledge and contacts on NATO.

1. See Waltz 1979; Walt 1987.

2. See Mearsheimer 1990; and Waltz 1993.

3. See Wallander 1999; and Walt 1997.

4. Keohane 1984. 
institutions-at least as far back as the Concert of Europe-may have multiple purposes. ${ }^{5}$ In addition to deterring external threats they cope with a variety of security problems, including instability, uncertainty, and relations among allies.

Whether an institution adapts to change depends on whether its assets-its norms, rules, and procedures - are specific or general, and on whether its mix of assets matches the kinds of security problems faced by its members. Assets specific to coping with external threats will not be effective for coping with problems of instability and mistrust, so alliances with only these assets will disappear when the threats disappear. Alliances that have specific institutional assets for dealing with instability and mistrust will be adaptable to environments without threats. Furthermore, alliances with general institutional assets will be less costly to adapt.

I use transaction costs approaches to develop hypotheses about when we should expect states to adapt institutions to environmental change rather than abandoning them or creating new ones. I then develop a preliminary test case of my hypotheses on adaptation of security institutions by explaining NATO's main institutional features during the Cold War. I document the changes and continuities in those features since 1990 and assess whether the persistence of NATO is due to its adaptation, made possible by its general and specific institutional assets.

\section{Institutions, Alliances, and Assets}

Alliances can be more than simply pieces of paper or aggregations of military power: as explicit, persistent, and connected sets of rules that prescribe behavioral roles and constrain activity, sometimes alliances are institutions. To understand why they are created, how they affect security relations, and whether they will persist, we need to develop hypotheses that draw on institutional theory. ${ }^{6}$

Analysts have turned to institutional theory to explain the persistence of NATO, focusing on the alliance's high degree of institutionalization as a central explanatory variable. ${ }^{7}$ States create costly institutions in anticipation of the cooperation they will be able to achieve. Institutional maintenance entails costs, but these costs are generally lower than those involved in creating new institutions. Changed circumstances, such as shifts in the distribution of power, changes in national policies, or the appearance of new cooperation problems are likely to alter the original cost/benefit relationship. Yet if the marginal costs of maintaining an existing institution outweigh the considerable costs of creating an entirely new set of norms, rules, and procedures, states will choose to sustain existing arrangements rather than abandon them. ${ }^{8}$ In addition, abandoning an existing institution risks competitive bargaining over alternative equilibria, with the chance that states will fail to agree, forcing them to settle

5. See Weitsman 1997; and Schroeder 1976.

6. Wallander and Keohane 1999.

7. See Duffield 1994; and McCalla 1996.

8. Keohane 1984. 
for suboptimal outcomes. ${ }^{9}$ Other things being equal, then, the more institutionalized a security coalition, the more likely it is to persist in the face of change in its environment.

This prediction, however, is not determinant enough to explain variation in institutional persistence and collapse. It predicts only that institutions will persist under changed circumstances when their expected value is greater than the expected value of creating new ones. It is difficult to test this in a systematic and prospective (rather than a post hoc) manner: how do we know when the expected value of an existing institution will be greater than that of a newly created one? It is too easy to conclude after the fact that an institution was considered worth preserving simply because it was preserved.

One possible explanation for institutional persistence is power: the United States, as the unrivaled power in the post-Cold War system, will determine which institutions will be adapted and which will disappear. The pattern of institutional persistence and decline after the Cold War does not support this hypothesis, however. Although NATO's persistence and adaptation is consistent with U.S. preferences, the overall pattern is not. The impressive success of the institutional adaptations of the European Union (EU) in the 1990s cannot be attributed to U.S. power and purpose, since the United States is at best indifferent to the EU. Similarly, the United States has not done much to support the Organization for Security and Cooperation in Europe (OSCE), the activities of which have broadened and become more institutionalized.

To push rational institutional theory to more determinant hypotheses on institutional choice and variation, we should begin with concepts from transaction costs approaches central to that body of theory: (1) the relative costs of potential alternative strategies as a key to choice, (2) contracting or governance problems as obstacles to cooperation, and (3) institutions as means to achieving and sustaining cooperative equilibria. In other words, a theory of institutional adaptation should be built on the logic of relative costs and the functions of institutions. ${ }^{10}$ This view suggests that variation in institutional adaptation is explained by variation in relative costs (such as provision of information), and by whether the rules, norms, and procedures of a given institution enable states to overcome obstacles to cooperation (such as provisions for sanctioning or bargaining).

What factors affect relative costs and functional effectiveness? An important variable for both is asset specificity, which is the degree to which an investment is "sunk" in a particular relationship or for a particular purpose. Specific assets facilitate particular transactions, and they confer efficiency gains for those particular transactions: they are well suited to the purpose for which they are used. General assets, as the term implies, are useful in a variety of transactions. They have the advantage of flexibility and potential efficiency across a broad range of activities, but without specialization they are unlikely to be as effective for a particular transaction. How-

9. See Fearon 1998; Morrow 1994; and Wallander 1999, chap. 5.

10. See Keohane 1984, chaps. 4-6; and Martin 1992. 
ever, although specific assets can confer efficiency, cost savings, and greater productivity, the more specific the asset, the less it can be adapted for different uses or when conditions change. ${ }^{11}$

In economics, variation in asset specificity can arise from customers served, location, human capital, or physical design. ${ }^{12}$ Asset specificity in a particular relationship between a seller and a customer can reduce the costs of the transaction, but the asset is an investment that increases the costs of alternatives not chosen. That is, by investing in one asset (such as a common standard in intra-alliance communications systems), states make alternative choices (such as communication with nonallies) more costly in comparison. Another example of a relation-specific asset is the Soviet-West European gas pipeline, which created mutual dependence and vulnerability because it rendered the alternatives more costly. ${ }^{13}$

Asset specificity also influences choice by affecting what is possible or effective, and thus it has a functional dimension as well, especially when the form of specificity is in location or physical design. Jeffry Frieden argues that income streams from economic assets that are site-specific, such as mines, can be appropriated, so it matters a great deal who holds possession of them. In contrast, income streams for multinational enterprises derived from their managerial skills or technological advances on a global scale cannot be appropriated simply by seizing a given factory, so the factory represents less of a costly investment than the mine would. ${ }^{14}$ David Lake offers the system of U.S. naval bases in the western Pacific as an example of asset specificity in the security realm-a case that combines relationship, site, and design specificity. ${ }^{15}$

When assets are specific to a given relationship, location, or purpose, transactions are more likely to be productive and successful. Investing in specific assets can be a risky business, however, in the face of change. Whether the asset will continue to support profitable transactions will depend on whether it is profitable to serve similar customers or to support similar transactions. After the Cold War, for example, sustaining the system of Pacific naval bases will be an effective, low-cost strategy only if it enables the United States to cope with a new security problem, such as China, to replace the Soviet Union.

General assets, in this framework, are more likely to be useful in the event of change. Although less effective for any given specific transaction, they are not tied to particular relationships, locations, or purposes. Extending the example of naval assets and U.S. military strategy in the Pacific, aircraft carriers are a general asset relative to naval bases. They were mobile and therefore useful in a broader range of military theaters, in alliance relations with a wider variety of countries, and for a greater range of plausible military missions in the region. In short, asset specificity

11. Williamson 1985, chap. 2.

12. Alt et al. 1999, 107.

13. Yarbrough and Yarbrough 1992, 25-26.

14. Frieden 1994, 567-68.

15. Lake 1999,8 . 
affects the opportunity costs open to economic or political actors contemplating alternative strategies. ${ }^{16}$

This framework provides a basis for predicting when states will choose to maintain existing institutions as opposed to abandoning them entirely or creating new, more costly ones. International institutions play a role in security relations by reducing transaction costs and making it possible for states to cooperate when it is in their interests to do so. Institutions vary in their rules, procedures, norms, memberships, and purposes. These institutional assets enable states to cooperate by providing resources, such as information on intentions or compliance; by establishing rules for negotiations, decision making, and implementation; and by creating incentives to conform to international standards necessary for multilateral action. Institutions vary widely in their assets. The nuclear nonproliferation regime has an elaborate system for monitoring the sale and use of nuclear technology, including an intrusive inspection system for non-nuclear member states. The Association of Southeast Asian Nations (ASEAN) Regional Forum, in contrast, shuns intrusiveness into the internal affairs of its member states and has a minimal formal structure. ${ }^{17}$

Developing contractual institutional theory to allow for variation in institutional assets is the link that allows us to generate hypotheses on variation in adaptation. Institutions with general assets will be adaptable to new problems. Because the assets are not specific to a given relationship, location, or purpose, using them for new purposes will be low cost and broadly effective.

In cases where institutional rules, norms, and procedures are highly asset specific, the adaptability of the institution to new circumstances will depend on whether the assets are specific to the obstacles or problems that members face. Because a relationship exists between the form of an institution and its function, ${ }^{18}$ even if an institution was previously highly effective in supporting cooperation within a particular set of relationships or coping with a particular set of obstacles, states will not adapt specific assets that are not cost effective.

If variation in asset specificity is the key to institutional adaptation, what explains variation in asset specificity? The answer lies in the relationship between institutional design (and assets) and variation in the costs and problems institutions may enable states to overcome. There are many ways to characterize the variety of security relations states face. An approach conceptually related to the broader rationalist perspective on variation in the forms of cooperation problems involves distinguishing between deliberate threats and problems arising from instability and mistrust. ${ }^{19} \mathrm{~A}$ state poses a threat when it has the intention and capability to attack or invade another or to coerce another state to adopt policies contrary to its national interests. ${ }^{20}$ Situations of threat are akin to those of collaboration, as in the prisoners' dilemma, in which the parties have an interest in exploiting one another even though they may

16. Ibid., 53-54.

17. See Wallander 1999, chap. 5; and Johnston 1999.

18. Williamson 1985, chap. 11.

19. Wallander 1999, chap. 3.

20. Walt 1991. 
find it in their mutual interest to cooperate conditionally through such mechanisms as mutual deterrence.

In the absence of a clear threat, states may face difficult security problems nonetheless. This has long been recognized in the problem of the security dilemma: although states may have benign intentions, they may fear that they face threats they do not recognize, leading them to adopt worst-case strategies, which themselves create insecurity. Being able to differentiate real threats from the diffuse possibility that they exist enables states to adopt better, more self-interested security strategies. ${ }^{21}$ In addition, though a state may not be the target of a threat, its security is at risk if its environment is plagued by instability, nearby conflicts such as ethnic disputes, and humanitarian crises. Although these conditions do not threaten the political or territorial integrity of a state directly, they can escalate vertically or horizontally, creating military, political, or refugee problems with the same security-diminishing effects as traditional threats.

The key point is that while deliberate threats and the problem of instability and mistrust can have similar effects on a state's security, their sources are qualitatively different, and dealing with them requires different policies and institutional mechanisms. Coping with deliberate threats requires political-military strategies of defense and deterrence-in short, counterthreats. Coping with instability and mistrust requires political strategies of assurance, mediation, and conflict prevention (that is, integration and engagement) and military strategies for cooperative intervention (such as humanitarian assistance or peacekeeping) using a variety of smaller scale and more diverse military contingencies than the kind of national defense used for dealing with invasion or coercion.

Therefore, we would expect that alliances, as institutions designed to enable states to cooperatively deal with the threat of invasion or coercion, would develop specific assets for mounting credible defense and deterrence. The specific political assets they would develop are joint policies, statements, and commitments designed to make deterrence and collective defense against the threat clear and credible. The specific military assets would be tailored to the particular threat facing the alliance (for example, the assets necessary for coping with a naval power will differ from those for coping with a land power). These assets entail military capabilities designed to defend against the threat (or threats) to the allied members, including the option of waging total war. Although alliances may negotiate with adversaries on behalf of their members, their primary purpose is not to resolve disagreements but to defend their members.

The specific assets designed for coping with instability will look quite different. Instability requires mechanisms to limit unilateral actions and procedures to limit competitive bargaining and make commitments possible so that states can negotiate and implement self-enforcing agreements. In order to achieve assurance and prevent misperception, states design political-military security institutions to foster integration and interdependence among the members so that they can reveal that they have 
neither the intention nor the capacity to pose a threat to one another. Integrated military command and forces limit unilateral defense policies, at least over the shortto-medium term. On the political side, states can be constrained by implementing certain domestic institutional procedures, such as civilian control of the military or democratic governance of security policy. ${ }^{22}$

To deal with security problems arising from regional conflicts and humanitarian crises, states need institutions that have specific assets for mediation and bargaining, rest on a presumption of legitimacy, and operate by including problematic states. Institutions that specialize in coping with instability, such as the OSCE, have a distinct political form as a result. On the military side, forces for peacekeeping missions need to be mobile, are less reliant on ground forces than those with a traditional defense mission, require multinational command, and operate under rules of engagement more akin to police forces than traditional militaries. ${ }^{23}$

An institution's assets need not all be specific, just as a firm's assets need not all be specific to customers or transactions. Institutions may have two types of general assets in their design. The first type of general asset is providing information to members. The basic obstacle to cooperation or exchange in social relations is uncertainty, and the basic way institutions reduce transaction costs arising from uncertainty is by providing information. ${ }^{24}$ Transparency and information provision are general assets: all institutions have them in one form or another, and the practices that provide them usually are designed to be flexible and applicable in a wide variety of cases. ${ }^{25}$ The second type are basic mechanisms that make all organizations work: procedures for deliberation, decision making, and implementation.

Although assets specific to dealing with the traditional security problems of invasion and coercion are distinct from those specific to dealing with instability and misperception, in practice institutional assets may be diversified. Alliances may develop practices for managing relations among members because they often arise out of the experience of defeating enemies, and one of the purposes of an alliance has been to enmesh weakened former enemies in the practices of conflict management, negotiation, and mediation. ${ }^{26}$ Although ostensibly motivated by common defense against external threats, alliances have often been motivated at least as much by security management among members as by collective defense concerns. This idea was behind Lord Ismay's observation that NATO was created to keep the Russians out, the Americans in, and the Germans down.

If the external threat an alliance was created to deter should disappear, the alliance will be more likely to persist if it already has developed institutional practices that will be cost effective in the new security environment. This brings us to our case: I expect that NATO has persisted after the Cold War not merely because it already exists (the sunk-costs argument), but because its Cold War institutional form in-

22. See Van Evera 1999; Fearon 1995; and Russett 1993.

23. United Nations 1990.

24. Keohane 1989, chap. 1.

25. Wallander 1999, chap. 8.

26. See Richardson 1999; and Schroeder 1976. 
cluded specific assets for achieving transparency, integration, and negotiation among its members, and because it developed general assets that could be mobilized to deal with new security missions. Although the threat NATO was created to meet has disappeared, NATO has proven adaptable after the Cold War because it had multiple purposes during the Cold War and developed assets to achieve them.

If the model is correct, then (1) NATO should be shedding the specific assets for coping with the external Soviet threat; (2) its members should be shifting its general assets to deal with new post-Cold War security problems; and (3) NATO's adaptations since 1990 have been built upon its preexisting specific assets for coping with instability, misperception, and mistrust. The model would be inconsistent with evidence that (1) NATO has persisted by shifting its Soviet-specific threat assets to deal with post-Cold War security problems; (2) it has not been able to mobilize its general assets to cope with its new security problems; or (3) NATO's adaptations since 1990 have not been built upon its preexisting specific assets for coping with instability and mistrust.

Before turning to the NATO case, it is important to clarify the underlying concepts of structure and agency implicit in this revised institutional theory. Derived from economic transaction-costs approaches, the argument is dependent on structural incentives and opportunities and how they affect strategic choice. However, the argument does not require — and I am not arguing — that the objectives, beliefs, and roles of individual states are irrelevant to institutional adaptation. Clearly, for example, U.S. priorities and military forces were essential to NATO's adaptations and actions in the 1990s, just as French and German commitment have been essential to the evolution of the EU.

What my model does argue is that agency does not sufficiently explain institutional change and adaptation. U.S. priorities and the Joint Chiefs of Staff may have been necessary for NATO's mission in Bosnia, but they were not sufficient: without the Supreme Allied Commander Europe (SACEUR) at NATO headquarters, U.S. agency would not have been enough. Institutional assets affect the costs and effectiveness of alternative strategies, but they do not determine purpose or set the valuation states place on national security objectives. A complete account of any case requires both structure and agency.

\section{A Test Case: NATO}

The Washington Treaty establishing the North Atlantic Alliance was signed on 4 April 1949. Its purpose was to deter a Soviet military attack in Western Europe and to defend Europe from an attack should deterrence fail. However, the alliance differed from traditional mutual aid or guarantee pacts in several respects important for understanding its institutional form during the Cold War. In addition to its external mission of deterrence and defense against the Soviet Union, the alliance was also intended to 
build peace and security among its members as democratic countries. ${ }^{27}$ In NATO parlance, the alliance was an Article 4 (peace and security) as well as an Article 5 (collective defense) treaty.

\section{NATO's Assets During the Cold War}

NATO grew from a political commitment to an elaborate political-military institution over the course of many years. The only institutional structure established by the treaty was the North Atlantic Council (NAC). Within its first year, the alliance had also established committees for defense, military, finances, and production. But the alliance's most distinctive assets-its integrated civilian and military staffs-were absent until the Korean War. North Korea's attack overcame the reluctance of alliance members to build up their military forces in the aftermath of World War II. In addition to raising its own force levels, the United States made its initial major commitment of forces to be deployed in Europe in late 1950, and the European members increased their own defense spending. In 1951, Supreme Headquarters Allied Powers Europe (SHAPE) was established. The alliance also created a civilian staff and the post of secretary-general to lead the political side of the alliance. ${ }^{28}$

These developments were general institutional assets designed to provide information among alliance members and enable them to consult and make effective decisions. The NAC and civilian staff developed over many years to cope with the requirements of alliance consultation and implementation of decisions. The strains of coping with recurrent alliance crises, such as that over flexible response in the 1960s or over West Germany's policy of Ostpolitik and the United States' policy of détente in the 1970s, led the members to deepen alliance mechanisms for consultation and consensus decision making over time..$^{29}$ These were problems not only of deterring the external Soviet threat but also of managing recurring differences among the allies about how to cope with the common threat in concrete policies: what Glenn Snyder has called the alliance dilemma. ${ }^{30}$ States are likely to have diverging preferences about how to cope with an otherwise common threat, so even allies need ways to help them negotiate on matters such as where forces will be stationed, who contributes what, and which diplomatic stands can be attributed to the alliance as a whole. ${ }^{31}$ The story of NATO's development is only partly told with reference to the Soviet threat, because the important details of the story also involve the relationship among the allies, their disagreements, and compromises. ${ }^{32}$

These political mechanisms were not specific to the Soviet threat nor to managing mistrust or disputes among the allies. They were organizational assets developed over many years to enable the alliance to discuss problems, to decide how to address

27. See Risse-Kappen 1995; and Osgood 1962.

28. See Kay 1998, chap. 3; and Kugler 1993, chaps. 2-3.

29. Theiler 1997.

30. Snyder 1984.

31. Morgenthau 1959.

32. See Osgood 1962; Haftendorn 1996; and Kugler 1993. 
them, and to implement decisions once they had been made. ${ }^{33}$ They were used to cope with the Soviet threat, but they were also used to manage problems among the allies, ranging from NATO's recurrent crises of credibility to the problem of preventing direct military conflict between Greece and Turkey.

NATO also developed organizational assets that enabled the members to implement policies. In the economic realm, NATO developed a set of committees and procedures for coordinating budgets, common spending on infrastructure, purchases, and other areas of alliance accounting. NATO's economic assets were not merely a function of its development as a military institution, since Article 2 of the Washington Treaty calls upon the members to eliminate conflict in their economic policies and to collaborate in economic affairs. However, without question the development of these assets was precipitated by the need for practical implementation of military policies and political cohesion over such issues as burden sharing and transparency in national military budgets and alliance contributions. These assets include NATO's Economic, Civil Budget, Military Budget, and Standardisation Committees as well as subordinate bodies for consumer and production logistics, emergency planning, and armaments cooperation.

Similarly, NATO's practices, procedures, and mechanisms for developing and implementing its military policy could be useful for a broad range of military missions beyond deterrence and defense. NATO's infrastructure for logistics, air defense and control, and reinforcement could be used in diverse military missions. The alliance's common infrastructure program enabled members' militaries to work together as complex and multipurpose organizations, not merely as military instruments to blunt a Soviet attack. The system of European basing infrastructure-America's "forward bases"-provided alliance members with an enhanced capability for military operations in a wide variety of contingencies. ${ }^{34}$

Most important, NATO's multinational integrated military command and the interoperability of its members' forces provided a general organizational capability. Although the degree of integration and interoperability never achieved NATO members' aspirations, this command was impressive nonetheless. NATO's procedures were a blend of national and alliance command. For the most part, NATO members' forces remained under full national command, which meant that all aspects of operations and administration remained the responsibility of national governments and their militaries. But at the same time, NATO members would assign specific forces under the operational command or control of a NATO commander at designated times for specific purposes, and they would assign operational command or operational control at a future date - that is, given certain contingencies. In practice, this meant that NATO could execute military exercises at regular periods to practice joint operations. Both the command staffs themselves and the actual forces would in this way develop experience in joint alliance military operations. The impetus for the

33. For a similar analysis, see Sandler and Hartley 1999, chap. 8.

34. Lake 1999, 153-55. The United States' global system of forward bases is not the same as NATO's military strategy of forward deployment on the intra-German border, although the terms are similar. 
integrated command structure and the interoperability of alliance forces was the Soviet threat, but it was also rooted in NATO's internal objectives of integration and transparency of its members' military forces and political processes. By design and by function, they were general assets.

In contrast, the alliance's national military forces, their deployment, and the military strategy worked out by alliance members over the years were specific to the Soviet threat. NATO's primary military asset for coping with the Soviet threat was its blend of nuclear and conventional forces. A U.S. nuclear commitment to NATO alone-what at first glance could seem a workable division of labor-was problematic because it raised questions of whether the United States had made a deep enough commitment to the security of Western Europe. As part of the 1951 Paris Agreement paving the way for West Germany to be admitted as a member, the United States pledged to maintain a substantial conventional military presence in Europe along with its extended nuclear deterrent..$^{35}$

In the 1960s, NATO faced crises of external credibility and internal alliance politics that shaped its specific threat-related assets. The development of Soviet strategic nuclear capability appeared to call into question the United States' commitment to escalate any conventional war in Europe and thus to undermine NATO's deterrent strategy. After years of efforts to craft a solution, NATO adopted and implemented the policy of flexible response. ${ }^{36}$ Flexible response entailed deployment of enormous numbers of substrategic nuclear weapons in Europe linked to U.S. strategic nuclear weapons through the prospect of escalation. NATO's nuclear deployments and strategy were specific assets for coping with the Soviet threat, not a military capability that could be used in a variety of situations.

The second major component of NATO's military strategy to cope with the Soviet threat was, notwithstanding the reliance on nuclear weapons, an enormous conventional military deployment in Western Europe. NATO's numbers never equaled those of the Soviet Union and Warsaw Pact, but they were impressive nonetheless. ${ }^{37}$ Furthermore, NATO's forces were forward-deploye d to be able to fight any Soviet attack with a full-scale effort from the earliest stages of a conflict. In addition to involving substantial numbers of West German military forces, this strategy required the deployment of allied forces in West Germany. The alliance also maintained high levels of readiness to compensate for NATO's smaller numbers of conventional forces. Like NATO's nuclear posture, these military assets were specific to the Soviet threat.

The alliance also developed practices, procedures, and principles specific to coping with security problems within the alliance, particularly those arising from the alliance's need to deal with the distinctive problem of Germany. By the early 1950s, it was clear that NATO would be unable to field the conventional forces considered necessary to deter and defend against Soviet forces without West Germany's participation in the alliance. Given Europe's fears of German power and intentions, an

35. Kugler $1993,71$.

36. See Haftendorn 1996; and Stromseth 1988.

37. See, for example, International Institute for Strategic Studies 1990, 232. 
unconstrained and fully re-armed sovereign Germany could be as great a potential threat as the Soviet Union. The solution was to allow German rearmament in the context of NATO's integrated command (and in conjunction with West Germany's simultaneous integration in the emerging European Economic Community). West Germany joined NATO in 1955 as a sovereign state with the right to arm, but it agreed not to create a general staff, effectively subordinating its armed forces to SACEUR. In this way, NATO's earliest institutional assets were designed to make Germany unable and other NATO members disinclined to rely on "national" defense policies and military strategies. ${ }^{38}$

The entangling effects of an integrated military command in West Germany's domestic political structure was not a by-product of alliance military efficiency but a deliberate strategy of security integration: by enmeshing a sovereign German republic in the Atlantic alliance, the allies hoped to implant support for the alliance in German domestic politics. ${ }^{39}$ NATO's political-military integration, supranational defense policy, and civilian and democratic control of the military and defense affairs were not related to the Soviet threat. The alliance's commitment to these procedures was a result of members' determination to prevent mistrust, unilateral defense policies, and the types of destabilizing security policies that had (in the members' eyes) led to Europe's wars. Germany was not the only target of NATO's internal integrative and transparency efforts and effects, although it was the most important one. NATO enmeshed Greece and Turkey in a web of relations, and their alliance membership helped to prevent the escalation of their disputes to full-scale war. ${ }^{40}$

Table 1 summarizes NATO's assets during the Cold War. Analyses defining NATO as an alliance for coping with the Soviet threat are not incorrect, but they are incomplete. Many of NATO's distinctive features were specific to deterring and defending against the Soviet threat, primarily its nuclear strategy and forward deployment of conventional forces designed to defeat a Soviet land war. But many of its assets were not limited to that military mission. Much of what we think of as distinctly NATOthe NAC, SHAPE, interoperability, coordination of the economics of defense, and the basic exchange of information among allies-are the assets a highly developed organization needs to accomplish the general tasks that all kinds of organizations undertake.

Furthermore, many of NATO's distinctive features had nothing to do with coping with the Soviet threat at all and were a result of NATO's more subtle purpose of preventing a cycle of mistrust, competition, and instability in security relations among its members. NATO therefore developed specific assets for coping with risks among its members-primarily but not exclusively with Germany in mind. These features include mechanisms for political-military integration, multinationality of alliance structures, supranational defense policy, and the principles and procedures of civilian democratic control of defense affairs.

38. See Osgood 1962, 45-46, 68-74. Exceptions to NATO's joint military planning are Iceland (which does not have a standing military), France since 1966, and Spain in the early years of its membership.

39. Hanrieder 1989, 39.

40. Krebs 1999, 369. 
TABLE 1. NATO's assets during the Cold War

Specific assets

General assets

Transparency (among members)

NAC (and civilian staff)

Practices and procedures for consultation

SHAPE (and integrated command structure)

Interoperability (among members)

Logistics, reinforcements, air defense

Common economic infrastructure

\author{
Article 5 commitment \\ Flexible response (strategy \\ and capabilities) \\ Positional defense/forward \\ deployment \\ High readiness
}

Political-military integration (among members)

Multinationality of command and forces

Supranational defense policy

Civilian/democratic control

\section{NATO After the Cold War: Key Events}

NATO began to change to a limited degree in the late 1980s as a result of the easing of the Cold War. ${ }^{41}$ The number and scale of alliance exercises declined as Gorbachev's Soviet Union reduced its military presence in Europe, arms control negotiations increased in number and scope, and the opposing alliances initiated a process of confidence-building measures. NATO also shifted its nuclear strategy indirectly, as a result of the U.S.-Soviet Intermediate-range Nuclear Forces Treaty of 1987, which eliminated a class of nuclear weapons that had been integral to the alliance's strategy for credibly threatening nuclear escalation.

NATO's real transformation began with the London Declaration of 1990, which stated that the alliance did not consider the Soviet Union and Warsaw Pact adversaries and invited them to establish diplomatic contacts with NATO. In line with this change in purpose, the alliance declared that it would reduce its reliance on flexible response, though it did not rule out the nuclear option. In November 1990 NATO and the Warsaw Pact signed the Treaty on Conventional Forces in Europe and a joint declaration on commitment to nonaggression, and all the members of the OSCE signed the Charter of Paris for a New Europe. These commitments, seen as formally ending the Cold War, were meant to establish a political and cooperative basis for security in Europe.

The alliance began a review of its military strategy, resulting in NATO's "new Strategic Concept" published at its November 1991 summit meeting in Rome. ${ }^{42}$ The

41. The research in this section is based on NATO primary sources and interviews with fifteen U.S. officials who were involved in different aspects of NATO's adaptation in the period 1991-99 and one analyst who was deeply involved in policy on NATO during that period. I secured a sample representing officials from offices dealing with NATO in the Department of Defense (military and civilian), Department of State, and National Security Council, including officials who had worked on these issues in Europe and in the United States. All of the officials I contacted agreed to be interviewed, although three requested anonymity.

42. The text can be found at $<w w w . n a t o . i n t / d o c u / c o m m / c 911107 a . h t m>$. 
concept affirmed that the core purpose of the alliance remained collective defense but declared that since the threat of a monolithic, massive military attack no longer existed, "the risks to Allied security that remain are multi-faceted in nature and multi-directional, which makes them hard to predict and assess." Security problems now arise "from the adverse consequences of instabilities that may arise from the serious economic, social, and political difficulties, including ethnic rivalries and territorial disputes, which are faced by many countries in central and eastern Europe." In addition, it identifies allied security interests in the southern Mediterranean and Middle East, as well as the global problems of terrorism, proliferation of weapons of mass destruction, and proliferation of ballistic missile technology. ${ }^{43}$

Following this change in concept came several institutional innovations. The North Atlantic Cooperation Council (NACC) was established in 1991 as a political body including NATO and former Warsaw Pact members (and the former Soviet republics once the Soviet Union broke apart in December 1991). NATO created the Partnership for Peace and approved plans for creating combined joint task forces at its summit in January 1994. In 1997, NATO invited Poland, Hungary, and the Czech Republic to join the alliance (which they did at the fiftieth anniversary summit in 1999), created the Euro-Atlantic Partnership Council (EAPC) to replace the NACC, and signed partnership and cooperation agreements with Russia and Ukraine.

The change in NATO's security doctrine resulted in a substantial reduction in its conventional and nuclear forces. The United States reduced its forward presence in Europe from 325,000 to 100,000 troops, and the European members cut their forces by more than 500,000 troops. By 1999, NATO land, sea, and air units had been reduced by $30-40$ percent, with only $35-60$ percent kept at a thirty-day readiness level (compared with 70-90 percent kept at a minimum of two days' readiness in 1990). In 1991, the United States and the Soviet Union agreed to eliminate groundbased theater nuclear forces, and NATO reduced its deployed theater nuclear forces by 80 percent. ${ }^{44}$

As a result, NATO shifted its military strategy from positional defense based upon its Main Defense Forces to the other two categories of NATO forces: Immediate and Rapid Reaction Forces and Augmentation Forces. While the Main Defense Forces still form the major element of NATO's force structures, the proportions are quite different than during the Cold War. By 1994, NATO had begun to reshape its integrated command structure, reducing the number of major NATO commands from three to two. Allied Command Channel was incorporated into Allied Command Europe (ACE), leaving the latter and Allied Command Atlantic (ACLANT), and resulting in the shuffling of the subordinate commands.

However, in the early period of the wars in Yugoslavia NATO found itself unprepared to deal with new security problems. Despite the rhetoric about peace and secu-

43. Author's interview with Daniel Hamilton (U.S. embassy in Germany 1993-94, Department of State Bureau for European Affairs 1994-96, Policy Planning Staff 1996-), December 1999, Washington, D.C.

44. The Transformation of NATO's Defence Posture, July 1997, available at <www.nato.int/docu/facts/ trans.htm>. 
rity in Europe and NATO's new missions, the United States in particular was reluctant to become involved. NATO still had a collective defense mindset and structure, and it had not exercised, planned, and practiced for anything other than its Cold War mission under Article 5. In both political and military circles of NATO member countries, there was a deep reluctance to shed NATO's collective defense capabilities, structures, and missions for the uncharted world of "non-Article 5" missions. "Every time the U.S. walked up to really dealing with Bosnia" in 1992-93, it confronted these political and military obstacles to NATO peace operations. ${ }^{45}$ Although the new Strategic Concept changed the alliance doctrine in principle, in practice real adaptation evolved, through Bosnia, more slowly. As the war escalated in 1992-93 and the UN proved unable to prevent the fighting and particularly the assault on civilians of all ethnic groups, attention turned to NATO.

With the rationale of supporting UN Security Council resolutions, in 1993 NATO undertook Operation Deny Flight and Operation Sharp Guard (a blockade to enforce the UN embargo of former Yugoslavia). NATO also began planning and training to aid in the protection of safe areas as well as the protection of UN Protection Forces (UNPROFOR) themselves. The latter mission was similar to existing NATO missions, because it entailed protecting the military forces of NATO member states and was a justified "quasi-Article 5" mission. ${ }^{46}$ During 1994 and 1995, NATO conducted a series of limited but escalating air strikes in defense of UN safe areas and UNPROFOR personnel. These missions reached a peak in September and October 1995 and ended with the Dayton agreement of November 1995.

As a result of the shift from threat-specific deployments and strategy, the military command structure needed to be adjusted. First, the number of commands was reduced from sixty-five command headquarters to twenty ${ }^{47}$ An important impetus for the change was the bad experience of dual-key command with the UN in Operation Deny Flight; after that, NATO members insisted on a unified command structure in any future operations, and the focus on adapting NATO's command to post-Cold War missions enhanced the leverage of those insisting on change. ${ }^{48}$

Second, the changed security environment required not only a simple reduction in commands but also a shift in their capacity and makeup. With non-Article 5 and out-of-area missions, NATO's “command structure needs to be as mobile as its forces." ${ }^{49}$ NATO's solution, approved in 1994, was to put into practice the combined joint task forces concept of establishing a mission-specific mobile command structure. NATO created new offices (a planning staff at SHAPE and a Crisis Coordination Center in Brussels) to adapt alliance practices to the new missions. Although

45. Author's interview with Andrew Winner (State Department 1986-96, Bureau of Political-Military Affairs and in the office of the Undersecretary of State for Arms Control and International Security Affairs), June 1999, Cambridge, Mass.

46. Author's interview with Andrew Winner; author's interview with Robert Hunter (U.S. Ambassador to NATO 1993-98), June 1999, Washington, D.C.; author's interview with senior defense official A (Department of Defense), June 1999, Washington, D.C.

47. NATO 1998, chap. 12.

48. Author's interview with Robert Hunter.

49. Author's interview with senior defense official A. 
officials generally agree that NATO has not yet gone far enough in this development, the process began with the implementation force/stabilization force (IFOR/SFOR) in Bosnia, and by 1999, when the crisis in Kosovo escalated, NATO was far more prepared for deployment of a combined joint task force. ${ }^{50}$

In the same period, the alliance had to confront the question of how an avowedly political-military organization with an exclusive membership could contribute to security in a Europe without threats. NATO's first attempt to deal with this problem was to create the NACC as a way of including nonmembers in political discussions. Although NACC would not have the decision-making importance of the NAC, its purpose was to enable its members to cope with security risks through transparency, improving civil-military relations, advancing defense conversion and reform, and consulting on political-military security matters. NACC was designed as an explicit outgrowth of NATO practices and paralleled existing institutions with matching summit, ministerial, and operational committee meetings from the beginning. ${ }^{51}$ Despite some promising contributions to the new security missions, however (particularly in implementing the Conventional Forces in Europe Treaty ${ }^{52}$ ), NACC's limitations were substantial and apparent very early in 1992. Real political decision making and consultation continued to be done in alliance structures, and nonmembers could see that alliance policy would be worked out first in the NAC before being presented in the NACC. The military cooperation and integration that were central to NATO's internal purposes were different in the NACC because its structure was not military. And since NACC had been structured as a mechanism for NATO-Warsaw Pact reconciliation, it did not include many important European countries that had been neutral.

NACC therefore did not stem the pressure for enlargement that developed in 1992 $93 .{ }^{53}$ One of NATO's advantages, supporters argued, was that the alliance's contribution to security during the Cold War had been in integration, supranational defense policy, and principles of civilian democratic control. To argue this and resist enlargement seemed a fundamental contradiction. The idea behind enlargement was that in an environment dominated by instability, NATO's experience and assets as an institution for cooperation and integration among members could be expanded. NATO could do for Central and Eastern Europe what it had done in integrating Germany into post-World War II Western Europe. NATO rules and practices would be leverage for shaping the aspirant members' political systems, and membership would

50. Author's interview with senior defense official A; author's interview with senior defense official B (Department of Defense), June 1999, Washington, D.C.; author's interview with Col. Steve Randolph (1993-94, Joint Staff NATO and West Europe branch; 1994-95 Special assistant to the chair of the Joint Chiefs of Staff; 1995-97 Chief of the Secretary of the Air Force's Staff Group), June 1999, Washington, D.C.; author's interview with Philip Gordon (International Institute for Strategic Studies 1994-98; 1998-99 National Security Council Bureau on Europe and NATO Affairs), June 1999, Washington, D.C.; author's interview with Kori Schake (NATO military expert, Joint Chiefs of Staff, Department of Defense 1990 94), September 1999, Washington, D.C.; author's interview with Greg Schulte (1992-98, International Staff-Bosnia for the Secretary General of NATO and Director of Bosnia Operations; 1998- National Security Council's Bureau for Implementation of the Dayton Accords), June 1999, Washington, D.C.

51. Author's interview with Kori Schake.

52. Wallander 1999, chap. 5.

53. Goldgeier 1999, 22-26. 
ensure that their defense policies and military capabilities would not be instruments for threatening one another. ${ }^{54}$

Despite its advantages in extending proven practices to the post-Cold War environment of security risks, enlargement was a problematic policy for several reasons, not least the inescapable fact that alliance purposes remained linked to the external commitment of Article 5. Furthermore, it was very clear that many countries in Europe would not become members any time soon, if ever. NATO needed something to overcome the weakness of NACC for integration without the strength the Article 5 commitment membership entails. ${ }^{55}$

The idea was a mechanism that would function on an operational and practical level and that "drew upon NATO's professional capabilities and traditions of working together." ${ }^{56}$ In particular, officials explicitly saw that what NACC lacked and what NATO had were the defense planning and exercises that gave member militaries a focus for cooperation. These activities had been the source of NATO's defense and security integration and had given the alliance influence in the members' national militaries and civil-military relations. "[Partnership for Peace] looked like something new, but NATO laid the groundwork for it." ${ }^{57}$ The idea was to generate military activities for nonmembers similar to those generated by NATO members in order to garner the same effects on cooperation as NATO. ${ }^{58}$

Since peacekeeping was an obvious post-Cold War mission, the original idea was to focus on limited peacekeeping operations. The program was to be called "Partnership for Peacekeeping," but when eighteen U.S. soldiers died in a peacekeeping operation in Somalia, the idea was changed to "Partnership for Peace." ${ }^{59}$ Its agreements (which are bilateral, between NATO and individual countries) provide for joint military planning, training, exercises, and peacekeeping.

The popularity of Partnership for Peace and the burst of activity surrounding it took most officials by surprise. Originally, partners (the term of choice for participants, rather than "nonmembers") were invited to observe exercises. As the military contacts resulting from these exercises proved successful, partner countries requested to participate and eventually to assist in planning the exercises, and SHAPE worked with the partners in this regard. ${ }^{60}$ Civilian governments eagerly sought the influence of NATO's practices and procedures on their own militaries, and the militaries were eager for the professionalization and association of cooperating with NATO militaries, especially after their experiences as Soviet clients.

54. Lugar 1997. See also Kay 1998, chap. 5.

55. Kupchan 1994.

56. Author's interview with Robert Hunter.

57. Author's interview with Stephen Flanagan (Department of State Policy Planning Staff, 1989-97 (Deputy Director, 1993-97, National Security Council Bureau on Europe and NATO Affairs, 1997-99), September 1999, Washington, D.C.

58. Author's interview with Andrew Winner.

59. Author's interview with Charles Kupchan (1993-94 National Security Council), June 1999, Washington, D.C.; author's interview with Andrew Winner; author's interview with Robert Hunter.

60. Author's interview with Andrew Winner; author's interview with Hans Binnendijk (1993-94 Deputy Director, Policy Planning Staff of the Department of State), June 1999, Washington, D.C. 
This process was far from smooth, however. NATO militaries, the U.S. military, in particular, had initial doubts about moving their activities away from planning and exercising for the traditional mission of collective defense and maintaining the firewall between members and nonmembers. Through the experience, however, NATO members' militaries became enthusiastic supporters of Partnership for Peace. At first, SHAPE was reluctant to share information that had been part of the alliance's integrated command structure and the basis of its interoperability-for forty years these procedures had been classified and kept from precisely the countries now joining Partnership for Peace. But it became clear that for NATO to implement Partnership for Peace activities, it would have to share the specifications, its standardization agreements, for NATO's forces-a multinational exercise simply would not work if, for example, the different countries' fuel hoses and nozzles did not fit together. So, gradually, the NATO command began to share its military planning, exercising, and implementation procedures with the partners and thus to invest in Partnership for Peace. NATO members' professional militaries had been reluctant to take on nonArticle 5 missions before 1994: Partnership for Peace was an important factor in changing the attitude of NATO members' militaries toward developing the capacity for peace operations. ${ }^{61}$

At the same time, many members were dissatisfied with how NATO's post-Cold War political development had lagged so far behind its military adaptation. This was the impetus behind creating the EAPC in 1997 as a forum for discussing political issues arising from Partnership for Peace (such as political authorization for military missions) and for considering the political side of security partnerships in Europe for nonmembers. In short, the idea was for the EAPC to develop the kind of relationship with the NAC that Partnership for Peace had with SHAPE. In testimony to the U.S. Congress, for example, U.S. secretary of defense William Cohen said that the EAPC creates "a consultation capability with NATO ... [that] provides a ready-made framework for consulting on political-military issues." 62 Robert Hunter argues that the EAPC is a significant development because "these people are on a daily basis walking around in the building together," and though an important difference exists between the decisions of the NAC and the discussions of the EAPC, the discussions and consultations at the heart of NATO are also central to the EAPC and are related to what goes on in the NAC. ${ }^{63}$ A senior defense official confirmed this, saying that NATO's political institutions during the Cold War were designed to build consensus and elicit views, and this intent and practice have been transferred to the partners in the EAPC. Nevertheless, he conceded that problems remain. During the Kosovo conflict, some partners (Russia, in particular) believed that NATO's obligation to consult entailed a decision-making role in non-Article 5 missions. "But it was clear

61. Author's interview with Andrew Winner; author's interview with senior defense official A; author's interview with Greg Schulte.

62. Defense Secretary William S. Cohen, U.S. Information Agency, Johnson's Russia List (electronic version), 23 April 1997.

63. Author's interview with Robert Hunter. 
that decision making takes place in the NAC and only there: that is how NATO works." 64

Many officials remain skeptical about whether the EAPC indicates that NATO has adapted politically to post-Cold War missions ${ }^{65}$ To give the EAPC the kind of decision-making power the NAC has would give nonmembers power over decisions like the mission in Kosovo. To keep the EAPC a forum for discussion and weak consultation but not decision making creates problems of accountability for partner countries. The solution to this dilemma is not clear. Ultimately, it lies in integrating the EAPC and NAC, but that means giving membership to partners. In addition to the question of extending NATO's Article 5 commitment to more countries, officials worry that a larger body cannot function as a decision-making forum, especially for non-Article 5 missions. ${ }^{66}$

Characteristically, however, officials do not seem too perturbed by these theoretical obstacles and express confidence that, regardless of what comes up in the future, by relying on what has worked in the past the alliance will adapt its practices and procedures well enough to get by. The big questions for NATO's future after Kosovo are its relationship with Russia, whether and how Europe will now develop its own defense and security capabilities, the impact of unsettling political-military problems that arose in the Kosovo crisis, and whether the alliance should enlarge again.

\section{NATO's Assets After the Cold War: Analysis}

As this brief history shows, in the early 1990s NATO began to shed its specific assets for coping with external threats. Even though NATO's declaratory mission had changed and its forces had been reduced, however, officials agree that its persistence in this period was not due to adaptation but to inertia and a general sense that it must not be allowed to disappear. Central to its persistence was U.S. leadership and determination to remain involved in European security through NATO and U.S. commitment and power to back this up. ${ }^{67}$ One reason for the United States' commitment was its risk-aversion to even the smallest prospect of Russia emerging as a threat. However, U.S. commitment—and European support—was also a result of NATO's internal assurance and stabilization purposes ${ }^{68}$ Members were determined to avoid "renationalization of defense policy" (an important term in NATO parlance) to keep the United States in Europe and to enable the European countries to avoid having to build expensive independent national military forces. A third reason for U.S. commitment was recognition that NATO's general assets for decision making and joint military action should be valuable for a broader range of post-Cold War missions: "we sought to adapt what was existing and build on what institutions we had, because it had taken a long time to build, for example, NATO's integrated military command.

64. Author's interview with senior defense official B.

65. Author's interview with Philip Gordon; author's interview with Andrew Winner.

66. Author's interview with Hans Binnendijk.

67. See Art 1996; and Glaser 1993.

68. Goldgeier 1999. 
We may end up with an all-European security institution and then NATO would go away or change, become an OSCE with teeth-maybe, but we did not know." ${ }_{99}$

This diffuse commitment saw the alliance though to about 1993, "but by then it had to adjust, not just persist." 70 The events in Bosnia led NATO's members to see that it could be used for post-Cold War security tasks because its core institutional features were general assets, not specific to external threats. The political structure for consultation and decision making that had been developed during the Cold War was a general asset. Officials point out that even during the Cold War, the NAC did not just talk about the Soviet threat and had always existed for the broader security purposes of its members, although the relative emphasis has changed. ${ }^{71}$

When asked why its members were able to turn to NATO at that point, officials answer that it is because NATO is a consensus-building institution that had developed norms and procedures for making and implementing decisions. ${ }^{72}$ This is true of many international organizations: what made NATO's assets for consultation and decision making different? NATO's political procedures and practices were unmatched among security institutions in their design for intensive consultation, commitment to consensus, aversion to the appearance of disarray, and concrete capacity for implementation. As important as the abstract commitments to consensus, officials explain, were the day-to-day procedures and practices that made consensus possible: bureaucratic tricks that made the alliance work. A good example is the "silence procedure." When the office of the secretary-general seeks to get agreement on a decision, it drafts a memo to the permanent representatives of all the member countries. The memo takes the form "I propose decision $X$, and unless I hear no from you, I will go ahead." Over the years, NATO's norms have developed such that countries do not want to "break silence," so these decisions tend to get passed. ${ }^{73}$

In other words, NATO could adapt to post-Cold War security in part because it is mundane: it is an organization of hundreds of daily interactions and procedures. NATO functions on a permanent basis and has bureaucracies with practices and procedures staffed by civilians from many countries who work together. ${ }^{74}$ "NATO's institutions gave us a base for finding cooperation.... The institution has nooks and crannies which are very helpful for getting cooperation going. ... [It] is a processoriented organization: we do not want to spend time talking about structure, but just do it." 75 The alliance's structures and practices, especially its elaborate committee system, allow countries to focus on specifics and practical matters; it is not an enormous, cumbersome forum for discussing big issues. Furthermore, NATO's structure

69. Author's interview with Stephen Flanagan.

70. Author's interview with Robert Hunter.

71. Author's interview with Robert Hunter; author's interview with Philip Gordon; author's interview with Andrew Winner; author's interview with senior defense official B.

72. Author's interview with Philip Gordon; author's interview with Greg Schulte; author's interview with Robert Hunter; author's interview with Richard Kugler (1993-97 RAND senior defense analyst on NATO), June 1999, Washington, D.C.

73. Author's interview with Greg Schulte.

74. Author's interview with Robert Hunter.

75. Author's interview with senior defense official B. 
ensures that progress becoming stalled in one area will not prevent progress in another. The patterns and methods of working that evolved during the Cold War have been extended to new post-Cold War security problems.

On the military side, NATO's incremental Bosnia operations made clear to its members by 1995 that because of its integrated military command structure NATO was adaptable to the post-Cold War European security environment. For some forty years, the alliance had created an infrastructure, a set of practices and procedures, and a culture of professionalism in a military command based at SHAPE in Belgium. Thousands of military officers from NATO's member countries have served tours of duty working not only for their national military services but also for the alliance itself. During the Cold War, the specific plans and exercises were tailored to dealing with the Soviet military in Europe, but with Bosnia, it became clear to NATO members that the alliance's military command structure-with its procedures for planning, exercising, and implementing military missions-was not limited to that specific military task. When asked whether any of NATO's Cold War practices and procedures were the basis for its adaptations in 1993-97, U.S. officials involved in the decisions during that period all point to the alliance's integrated military command structure, characterizing it as "a clear connection to the Cold War," "sacrosanct" to the alliance, "the center of gravity within NATO," and "what NATO is."

The integrated command structure as a general asset is crucial to understanding why NATO - and not other institutions, such as the UN or the Western European Union (WEU) — can act for post-Cold War military missions in Europe. "NATO has the military structure: look at Kosovo. The UN failed in Bosnia: it can do certain kinds of peacekeeping operations and humanitarian missions very well. But military missions require command and control, so this means NATO. Military command is crucial to what NATO does well." 77 NATO has the headquarters with planning, logistics, and intelligence staffs, including military personnel who have all planned, trained, exercised, and schooled together for years and developed a deep trust. ${ }^{78}$ "If, for example, NATO were just the Article 5 commitment without any of its assets, it would be the WEU. What made NATO possible in the 1990s was what was developed in the Cold War to deal with the Soviet threat and the alliance's internal tasks."79 One official said that the OSCE was considered as a vehicle for dealing with Yugoslavia, but officials recognized what it could and could not do. The OSCE is best at establishing norms and standards for political and human rights. "We do not need NATO for every security issue, but we did need it to be able to react to the ones that were on the agenda in the 1990s." 80

Why were NATO's military command structure and political decision-making procedures general, rather than specific, assets? Because, observed a senior defense

76. Author's interviews with senior defense official A, Robert Hunter, Kori Schake, and Andrew Winner, respectively.

77. Author's interview with senior defense official B.

78. Author's interview with Greg Schulte.

79. Author's interview with Philip Gordon.

80. Author's interview with Daniel Hamilton. 
official, "through its political consultation, integrated military command, and organizations for implementation, NATO is able to do the three things that have to be done for any policy: mobilize, organize, and implement." ${ }^{81}$ Although developed during the Cold War, these capacities translate into post-Cold War missions and are crucial for multilateral security missions. While those who value efficiency bemoan NATO's slowness, the official noted, NATO "is not for maximum efficiency, but for acting together." 82 Another official, when asked why NATO has been able to adapt, answered that it is because all political-military missions require planning, and "during the Cold War, that is what NATO did." 83 And another official answered that it is NATO that has the tools for action, listing the integrated military command, logistics, command-control-communication, and the structures for coming to a coherent and cohesive consensus, whereas the UN and the OSCE do not. ${ }^{84}$ The political issues of non-Article 5 missions make the process more difficult, he observed, but the planning mechanism is basically the same: procedures for generating forces and readiness are on the books, the militaries understand them, and governments are accustomed to and ready for them.

However, just as clearly as Bosnia demonstrated that NATO's political consultation and integrated command structures were general assets that made it adaptable to the new security environment of risks and non-Article 5 conditions, it also demonstrated that NATO lacked important specific military assets for dealing with out-ofarea non-Article 5 contingencies. The alliance's potential new military missions require smaller, lighter, and mobile forces with expertise and training in peacekeeping, humanitarian relief, and peace enforcement, in stark contrast to the Cold War mission of positional defense. This process of creating post-Cold War specific military assets began both among members and in conjunction with Partnership for Peace.

NATO's evolving non-Article 5 capability is the self-contained command arrangement, the combined joint task force, which is rooted in the alliance's Cold War assets. NATO's core combined joint task force is the ACE Rapid Reaction Corps (ARRC), which was the command structure used to create the NATO peacekeeping force in Bosnia. ${ }^{85}$ Having deployed this basic command headquarters along with military forces immediately after the Dayton agreement, NATO relied on existing alliance practices to manage deployments: as ARRC was moved out in the course of regular troop rotations, the new deployments were organized on the basis of national sectors, as had been NATO's practice in West Germany during the Cold War, to "minimize the interface" between national military forces.$^{86}$ Even the process by which these command mechanisms are created and activated is a direct extension of NATO's Cold War procedures: a member through its permanent representative will bring the issue of a mission to the NAC, which then discusses and decides whether to request a

81. Author's interview with senior defense official B.

82. Ibid.

83. Author's interview with Greg Schulte.

84. Author's interview with Stephen Flanagan.

85. Author's interview with senior defense official A; author's interview with Robert Hunter.

86. Author's interview with Col. Steve Randolph. 
study, and if so, a request goes to the Military Committee, which puts together a plan that goes back to the NAC and member countries for debate and decision. This same process has been used throughout NATO's history and emerged directly from SHAPE's practices. ${ }^{87}$ So, although NATO did not have a specific military asset for dealing with out-of-area missions, it built on its general military asset of integrated military structure to create this capacity. Officials explain that combined joint task forces are among NATO's most important adaptations, and that they are an adaptation of its integrated command structure and an innovation within NATO's procedures and practices. ${ }^{88}$

Similarly, the different political-military requirements of post-Cold War missions have resulted in NATO building on one of its specific assets for dealing with internal risks: the multinationality of its command and forces. Multinationality served two functions during the Cold War: it was the basis for political-military integration to foster assurance among the members, and it was the mechanism for preventing the "renationalization" of defense policies. ${ }^{89}$ Multinationality is not needed for military purposes: "multinationality in NATO is a tool of integration, not efficiency." ${ }^{90}$ Multinationality "is a way of expressing political solidarity," which is particularly important for non-Article 5 missions because legitimacy is an issue. ${ }^{91}$

When NATO members committed to enlargement they turned to practices and mechanisms that had been the basis for the political-military integration of new members during the Cold War. Those involved in preparing Poland, Hungary, and the Czech Republic for membership said that the process and standards were a direct extension of NATO's established practices. For example, RAND developed a "defense improvement plan" establishing membership standards. The analysis quantified NATO members' defense postures (using indicators like readiness, ratio of military personnel to civilians, level of technology, degree of modernization, infrastructure, and resupply and reinforcement parameters), enabling RAND to establish the NATO average and then to compare these standards to those of aspirant countries. Governments could thereby see exactly what they had to change-particularly in terms of cutting quantity and building quality-to qualify for membership. Rather than vague exhortations and criticisms, these standards made it easier for civilian and military officials to agree to bring their militaries up to NATO standards..$^{92}$ NATO's own study on enlargement is very conservative in this regard: it cautions that "as a general principle, we should avoid new forms of contribution to NATO collective defense which would complicate unnecessarily practical cooperation among Allies and the Alliance's decision-making process." ${ }^{93}$ Indeed, some officials believe that enlarge-

87. Author's interview with Philip Gordon; author's interview with Kori Schake.

88. Author's interview with Charles Kupchan; author's interview with Col. Steve Randolph; Author's interview with senior defense official B, who conceded that the mission in Kosovo was 85 percent the U.S. Air Force.

89. Author's interview with Daniel Hamilton.

90. Author's interview with Charles Kupchan.

91. Author's interview with senior defense official A.

92. Author's interview with Richard Kugler; author's interview with Daniel Hamilton.

93. NATO 1995, 17. 
ment is too much tied to Cold War procedures and practices. ${ }^{94}$ One official pointed out that enlargement's Cold War precedent is specified in Article 10: "NATO always builds on what it has done previously." 95

However, although officials agree that enlargement has been a post-Cold War practice clearly built on NATO's earlier practices for coping with security risks through integration, they disagree on how explicitly the "German question" has influenced this adaptation. Some officials argue that the rationale for enlargement explicitly relies on the German case as a model for potential new members. ${ }^{96}$ Others do not draw this parallel explicitly, though they do say that if NATO decides to accept new members, it would need to do so through a structure that involves them in military cooperation through political relations, as was the case with Germany. ${ }^{97}$ Yet other officials see no direct extension of the practice because when Germany was admitted it was a defeated and occupied country that its neighbors feared would reemerge as a threat, which is not the case for new members. ${ }^{98}$ That this variety of views exists was confirmed by an official who was involved in the decisions at the time and said that whether NATO's Cold War practices and precedents mattered for enlargement depended on the position and perspectives of the individual being asked..$^{99}$

NATO's third major adaptation after the Cold War, Partnership for Peace, was built on the alliance's previous practices of direct military-to-military work, exercises, and democratic control of the military. ${ }^{100}$ Officials agree that the strength of Partnership for Peace is its practical, concrete program for security cooperation, which focuses on military missions, planning, and exercises: "The whole point of PfP [Partnership for Peace] was to teach them [partners] how NATO does these things." 101 This ability was unique to NATO as a highly institutionalized military alliance. ${ }^{102}$ In explaining why Partnership for Peace became so central to NATO's post-Cold War development, one official said that it was "because NATO is military: we do not work with finance ministries." ${ }^{103}$ Others attribute its success to being demand driventhe partners wanted it - but it was supply driven as well, since military planning is what NATO does best. ${ }^{104}$ As a result, when Implementation Force (IFOR) was created, some partners were ready to work closely with NATO in Bosnia, and by 1999 any partners participating in the Kosovo Force (KFOR) already had the procedures and planning they needed to work as part of NATO forces.

Partnership for Peace's own procedures have been developed by relying on NATO's existing practices and structures. In addition, its Planning and Review Process was

94. Author's interview with Hans Binnendijk; author's interview with Charles Kupchan.

95. Author's interview with Philip Gordon.

96. Author's interview with Richard Kugler; author's interview with Philip Gordon.

97. Author's interview with senior defense official B; author's interview with Robert Hunter.

98. Author's interview with Andrew Winner; author's interview with Col. Steve Randolph.

99. Author's interview with Charles Kupchan.

100. Author's interview with senior defense official A.

101. Author's interview with Col. Steve Randolph.

102. Author's interview with Hans Binnendijk.

103. Author's interview with Robert Hunter.

104. Author's interview with senior defense official B; author's interview with Hans Binnendijk. 
explicitly built on NATO's Defense Planning Process because the latter worked and because it could most easily integrate partners into NATO's way of doing things and could shape their militaries. ${ }^{105}$ The mechanism, in turn, provides for "partnership goals," which are themselves like NATO's "defense goals," which specify how to make forces interoperable-particularly in terms of resupply and logistics-so that when they deploy they fit into NATO missions. Classified information is still kept from partners, but otherwise they have access to and practice nearly all NATO procedures and standards. ${ }^{106}$

In this way, Partnership for Peace has become the mechanism for extending integration and interoperability beyond NATO members, and these, in turn, have served as the basis for NATO's adaptability to its political and military nonthreat security missions. One official called interoperability the key to the counterfactual of whether the United States and other European countries would be in Bosnia or Kosovo if NATO had not been built during the Cold War: without NATO, there would have been no interoperability, and without interoperability, "the nozzles would not fit" and the countries could not act. ${ }^{107}$ Another official said interoperability had been key to the NATO mission with Partnership for Peace partners in Bosnia, although he emphasized the importance of "communication capacity" and knowledge of procedures as much as hardware interoperability. ${ }^{108}$

Some officials argue that by 1997 Partnership for Peace had developed to such an extent that its activities included or related to nearly every NATO activity except the specific core commitment of collective defense embodied in Article 5. Furthermore, NATO established the Partnership Coordination Cell in Mons, Belgium-which, though not part of SHAPE, works closely with it. ${ }^{109}$ Consequently, military officers from member and nonmember countries regularly work together on most of the planning activities that have undergirded post-Cold War integration, assurance, and supranational defense policy within the alliance. Partners are not within the military command itself, but their participation is "kind of like being in a magnetic fieldthey are drawn into how NATO works." ${ }^{110}$ Many officials argue that the only difference between NATO members and partners is the commitment by members to collective defense. ${ }^{111}$ Partners are "de facto members: they plan, exercise, and consult." 112 Although Article 5 is an important political difference between members and partners, it has little effect on NATO's daily military activities. Virtually the entire structure of NATO except Article 5 has been incorporated into the Partnership for Peace

105. Author's interview with Kori Schake; Cook et al. 1997, 10-11.

106. Author's interview with senior defense official A; Williams 1997, 233.

107. Author's interview with Philip Gordon.

108. Author's interview with senior defense official A.

109. Author's interview with Greg Schulte.

110. Author's interview with Robert Hunter.

111. Author's interviews with Gen. George Joulwan, June 1999, Arden, N.Y.; author's interview with Andrew Winner; author's interview with Hans Binnendijk; author's interview with senior defense official B.

112. Author's interview with Hans Binnendijk. 
structure; moreover, according to one official, "Since 1994 NATO has been an Article 4 institution." "113 Another official, who takes a rather skeptical view of NATO's public rhetoric, observed that "NATO likes to use the term 'habits of trust and cooperation,' and while it is to a certain extent [used] for publicity, it actually does have meaning and significance." 114

One could argue that given how demand driven Partnership for Peace was, its evolution was a functional response and did not depend on NATO's previous Cold War assets. However, all of the officials who were asked about this strongly disagreed: "[Partners] wanted to be part of the club and so the club defined how they would participate and develop, and that depended on how NATO worked already." 115 Although NATO cannot dictate the defense policies, military practices, and civilianmilitary relations of nonmembers, its influence works through the aspirations of nonmembers: they want to be like NATO members and so by being involved in Partnership for Peace activities they are shaped to adopt NATO practices. ${ }^{116}$

Of course, for U.S. officials to insist that Article 5 is not that significant in NATO activities is a bit disingenuous, especially since partners have no claim on NATO decision making, and the United States would never give up its veto power. The important point, however, is not that membership and Article 5 are meaningless but that much of what the alliance is and has done since the Cold War is not tied to the hallmark of Cold War NATO: coping with the Soviet threat.

Table 2 summarizes NATO's post-Cold War assets. As the table indicates, NATO has clearly adapted to the post-Cold War European security environment. During the Cold War it developed the specific assets of political-military integration and multinational command and forces to create assurance and supranational defense policy among its members. These assets have proven even more valuable for legitimacy in coping with security risks in Europe after the Cold War. NATO's general political assets for consultation and decision making, its general military assets for planning and implementing missions, and its specific assets for fostering integration, assurance, and supranational defense policy within alliance structures were the basis for its adaptation and thus for its persistence.

Nothing I have written about the significance of NATO's institutional features denies the importance of U.S. power and policy in NATO's persistence. But U.S. influence alone does not sufficiently explain institutional form more generally, as indicated by the cases of the EU and the OSCE referred to earlier. U.S. efforts to adapt NATO to a new security environment have relied on NATO's assets developed during the Cold War. In the absence of NATO's institutional structure, the United States would not have been able to create its assets as we now observe them and might not even have attempted to do so.

113. Author's interview with Gen. Joulwan.

114. Author's interview with Philip Gordon.

115. Author's interview with Hans Binnendijk.

116. Author's interview with senior defense official B; author's interview with Richard Kugler. 
Specific assets

General assets

General assets

Transparency (members and partners)

NAC (and civilian staff)

Practices and procedures for consultation

SHAPE (and integrated command structure)

Interoperability (members and partners)

Logistics, reinforcements, air defense

Common economic infrastructure

$\begin{array}{ll}\text { Article } 5 \text { commitment } & \begin{array}{c}\text { Political-military integration } \\ \text { Residual deterrence }\end{array} \\ \text { (members and partners) } \\ \text { Combined joint task forces } \\ \text { (members and partners) } \\ \text { Partnership for Peace (and } \\ \text { Partnership Coordination Cell } \\ \text { in Mons) } \\ \text { Multinationality of command and } \\ \text { forces (NACC, EAPC, Permanent } \\ \text { Joint Council) } \\ \text { Supranational defense policy } \\ \text { Civilian/democratic control }\end{array}$

\section{Conclusions}

During the Cold War, NATO developed general assets for political consultation and decision making, and for military planning, coordination, and implementation. These assets were developed primarily, though not solely, for coping with the threat of a Soviet military attack. To cope with that threat, it also developed specific assets for deterring and fighting a European or global war with the Soviet Union. It also developed practices and procedures for fostering integration among its members to address European security problems that arose from fear, uncertainty, and "national" defense policies with militaries not subject to democratic civilian control.

When the security environment changed in the 1990s, NATO members turned to the alliance to address new security problems because NATO's general assets made it an effective political-military security institution capable of dealing with these new concerns. In some areas, NATO's assets have undergone a great deal of adaptation-in particular, a reduction in the number of commands and the development of combined joint task forces based on NATO military practices. In other areas, however, such as achieving multinationality of commands and forces, NATO's aspirations still exceed its achievements. In other areas, some new assets have emerged-in particular, Partnership for Peace, the NACC, and the EAPC - and through these mechanisms NATO has incorporated nonmembers into virtually all of its practices except those involving Article 5 (collective defense). Yet all of these new assets were built on NATO practices and procedures developed during the Cold War, including such mundane details as how to conduct training exercises and NATO's encompassing principles of transparency, integration, supranational defense, and civilian control. 
Furthermore, while NATO's post-Cold War structure has evolved from its Cold War general and specific assets for coping with instability and mistrust, it has clearly shed its specific assets for dealing with the Soviet threat. Thus, as a test case-one clearly still in the making-NATO's persistence through its adaptation to new conditions is consistent with the hypotheses derived from my institutional model.

This research should be extended to a comparative analysis of other security institutions and practices and their adaptation to the post-Cold War security environment. Fortunately, many cases exist, including such organizations as the WEU and the UN, regimes based on arms control treaties like the Conventional Forces in Europe Treaty and the nonproliferation treaties, and such practices as peacekeeping and conventions of sovereignty and human rights. These many cases will provide variation in the dependent variable of institutional adaptation, which, of course, this single case study of NATO does not.

To further develop institutional theory, we should investigate the interaction between institutional assets and assets held by countries themselves. As I have shown, during the Cold War NATO developed assets such as the integrated military command at SHAPE and the NAC as a multilateral consensus and decision-making body. In addition, NATO's existence has affected the military and political assets of the member countries themselves. Although alliance members did not specialize to the degree that might be common for participants in a business enterprise, to some extent NATO's European members chose not to develop extensive naval forces or substantial airlift capabilities because they knew the United States would provide these capabilities to the alliance. ${ }^{117}$ In probably the most dramatic case, NATO's existence constrained Germany from acquiring nuclear weapons or creating a general staff. Anyone familiar with the foreign-policymaking apparatus of countries such as Germany and the United States knows that NATO's existence has shaped departments and procedures within national foreign and defense ministries. Insofar as NATO has affected how its members have invested in their own national assets, the choices of post-Cold War institutions and security arrangements may be shaped in even more far-reaching ways than I have explored in this article.

More ambitiously, the study of institutional persistence and adaptation would benefit greatly from the development of a more general framework of variation in institutional forms and function. The theory I develop here is cast in terms of problems of security, but these issues are analytically related to general problems of international cooperation confronting states. There are now several efforts to develop theories about how institutions matter and to explain variation in institutions and their effects. ${ }^{18}$ This research has the potential to more clearly elucidate the relationships between institutional design and international outcomes. Asset specificity is only one aspect of institutional design, but it is an important piece of the puzzle of institutional change and adaptation that was neglected during the Cold War. ${ }^{119}$ Many analysts

117. I am grateful to David Lake for suggesting the importance of members' asset specificity. For evidence of institution-induce d asset specificity of NATO members, see Lake 1999, chap. 5.

118. See Martin and Simmons 1998; Botcheva and Martin 1999; and Wallander 1999.

119. Jervis 1997. 
have observed that NATO is an unusual case, but if we are to understand the role played by asset specificity in institutional persistence, we should integrate the study of NATO more firmly into the broader subject of institutional theory because it is one of the most highly developed institutions in the international system.

\section{References}

Alt, James E., Fredrik Carlsen, Per Heum, and Kare Johansen. 1999. Asset Specificity and the Political Behavior of Firms: Lobbying for Subsidies in Norway. International Organization 53 (1):99-116.

Art, Robert J. 1996. Why Western Europe Needs the United States and NATO. Political Science Quarterly 111 (1):1-39.

Botcheva, Liliana, and Lisa L. Martin. 1999. Institutional Effects on State Behavior: Typology and Hypotheses. CFIA Working Paper No. 99-05. Cambridge, Mass.: Weatherhead Center for International Affairs.

Cook, Debra A., Mark A. Daniels, Michael P. Fleming, John R. Hawkins III, and Erin A. Reffett. 1997. Partnership for Peace: The Vector for European Security. National Security Program Discussion Paper 97-002. Cambridge, Mass.: John F. Kennedy School of Government.

Duffield, John S. 1994. NATO's Functions After the Cold War. Political Science Quarterly 109 (5): $763-87$.

Fearon, James D. 1995. Rationalist Explanations for War. International Organization 49 (3):379-414.

- 1998. Bargaining, Enforcement, and International Cooperation. International Organization 52 (2):269-305.

Frieden, Jeffry A. 1994. International Investment and Colonial Control: A New Interpretation. International Organization 48 (4):559-93.

Glaser, Charles L. 1993. Why NATO Is Still Best: Future Security Arrangement s for Europe. International Security 18 (1):5-50.

Goldgeier, James M. 1999. Not Whether but When: The U.S. Decision to Enlarge NATO. Washington, D.C.: Brookings Institution.

Haftendorn, Helga. 1996. NATO and the Nuclear Revolution: A Crisis of Credibility, 1966-67. Oxford: Clarendon Press.

Hanrieder, Wolfram. 1989. Germany, America, Europe: Forty Years of German Foreign Policy. New Haven, Conn.: Yale University Press.

International Institute for Strategic Studies. 1990. The Military Balance: 1989-90. London: International Institute for Strategic Studies.

Jervis, Robert. 1978. Cooperation Under the Security Dilemma. World Politics 30 (2):167-214.

. 1997. System Effects: Complexity in Political and Social Life. Princeton, N.J.: Princeton University Press.

Johnston, Alastair Iain. 1999. The Myth of the ASEAN Way? Explaining the Evolution of the ASEAN Regional Forum. In Imperfect Unions: Security Institutions over Time and Space, edited by Helga Haftendorn, Robert O. Keohane, and Celeste A. Wallander, 287-324. Oxford: Oxford University Press.

Kay, Sean. 1998. NATO and the Future of European Security. Lanham, Md.: Rowman and Littlefield.

Keohane, Robert O. 1984. After Hegemony: Cooperation and Discord in the World Political Economy. Princeton, N.J.: Princeton University Press.

- 1989. International Institutions and State Power. Boulder, Colo.: Westview Press.

Krebs, Ronald R. 1999. Perverse Institutionalism: NATO and Greco-Turkish Conflict. International Organization 53 (2):343-77.

Kugler, Richard L. 1993. Commitment to Purpose: How Alliance Partnership Won the Cold War. Santa Monica, Calif.: RAND.

Kupchan, Charles A. 1994. Strategic Visions. World Policy Journal 11 (3):112-22. 
Lake, David A. 1999. Entangling Relations: American Foreign Policy in Its Century. Princeton, N.J.: Princeton University Press.

Lugar, Richard G. 1997. Russia, Its Neighbors, and an Enlarging NATO. New York: Council on Foreign Relations.

McCalla, Robert B. 1996. NATO's Persistence After the Cold War. International Organization 50 (3): 445-75.

Martin, Lisa L. 1992. Interests, Power, and Multilateralism. International Organization 46 (4):765-92.

Martin, Lisa L., and Beth Simmons. 1998. Theories and Empirical Studies of International Institutions. International Organization 52 (4):729-57.

Mearsheimer, John J. 1990. Back to the Future: Instability in Europe After the Cold War. International Security 15 (1):5-57.

Morgenthau, Hans J. 1959. Alliances in Theory and Practice. In Alliance Policy in the Cold War, edited by Arnold Wolfers, 184-212. Baltimore, Md.: Johns Hopkins University Press.

Morrow, James D. 1994. Modeling the Forms of International Cooperation: Distribution Versus Information. International Organization 48 (3):387-423.

NATO. 1995. Study on NATO Enlargement. Brussels: NATO Information Office.

1998. NATO Handbook. 50th anniversary ed. Brussels: Office of Information and Press.

Osgood, Robert E. 1962. NATO: The Entangling Alliance. Chicago: University of Chicago Press.

Richardson, Louise. 1999. The Concert of Europe and Security Management in the Nineteenth Century. In Imperfect Unions: Security Institutions over Time and Space, edited by Helga Haftendorn, Robert O. Keohane, and Celeste A. Wallander, 48-79. Oxford: Oxford University Press.

Risse-Kappen, Thomas. 1995. Cooperation Among Democracies: The Euopean Influence on U.S. Foreign Policy. Princeton, N.J.: Princeton University Press.

Russett, Bruce M. 1993. Grasping the Democratic Peace: Principles for a Post-Cold War World. Princeton, N.J.: Princeton University Press.

Sandler, Todd, and Keith Hartley. 1999. The Political Economy of NATO: Past, Present, and into the 21st Century. Cambridge: Cambridge University Press.

Schroeder, Paul. 1976. Alliances, 1815-1945: Weapons of Power and Tools of Management. In Historical Dimensions of National Security Problems, edited by Klaus Knorr, 227-62. Lawrence: University Press of Kansas.

Snyder, Glenn H. 1984. The Security Dilemma in Alliance Politics. World Politics 36 (4):461-95.

Stromseth, Jane E. 1988. The Origins of Flexible Response: NATO's Debate over Strategy in the 1960s. New York: St. Martin's Press.

Theiler, Olaf. 1997. Der Wandel der NATO nach dem Ende des Ost-West-Konfliktes. In Kooperation jenseits von Hegemonie und Bedrohung, edited by Helga Haftendorn and Otto Keck. Baden-Baden: Nomos.

United Nations. 1990. The Blue Helmets: A Review of United Nations Peace-keeping. 2d ed. New York: UN Department of Public Information.

Van Evera, Stephen. 1999. Causes of War: Power and the Roots of Conflict. Ithaca, N.Y.: Cornell University Press.

Wallander, Celeste A. 1999. Mortal Friends, Best Enemies: German-Russian Cooperation After the Cold War. Ithaca, N.Y.: Cornell University Press.

Wallander, Celeste A., and Robert O. Keohane, 1999. Risk, Threat, and Security Institutions. In Imperfect Unions: Security Institutions over Time and Space, edited by Helga Haftendorn, Robert O. Keohane, and Celeste A. Wallander, 21-47. Oxford: Oxford University Press.

Walt, Stephen M. 1987. The Origins of Alliances. Ithaca, N.Y.: Cornell University Press.

— 1991. The Renaissance of Security Studies. International Studies Quarterly 35 (2):211-40. 1997. Why Alliances Endure or Collapse. Survival 39 (1):156-79.

Waltz, Kenneth N. 1979. Theory of International Politics. Reading, Mass.: Addison-Wesley. 1993. The Emerging Structure of International Politics. International Security 18 (2):44-79.

Weitsman, Patricia A. 1997. Intimate Enemies: The Politics of Peacetime Alliances. Security Studies 7 (1):156-92. 
Williams, Nick. 1997. Partnership for Peace: Permanent Fixture or Declining Asset? in NATO's Transformation: The Changing Shape of the Atlantic Alliance, edited by Philip H. Gordon, 221-33. New York: Rowman and Littlefield.

Williamson, Oliver E. 1985. The Economic Institutions of Capitalism: Firms, Markets, Relational Contracting. New York: Free Press.

Yarbrough, Beth V., and Robert M. Yarbrough. 1992. Cooperation and Governance in International Trade: The Strategic Organizational Approach. Princeton, N.J.: Princeton University Press. 